\title{
A STUDY OF POTENTIAL OUTPUT AND OUTPUT GAP IN THE CZECH REPUBLIC
}

\author{
V. Adamec, L. Střelec \\ Received: November 30, 2011
}

\begin{abstract}
ADAMEC, V., STŘELEC, L.: A study of potential output and output gap in the Czech Republic. Acta univ. agric. et silvic. Mendel. Brun., 2012, LX, No. 2, pp. 9-16

Analysis of economic cycle is of enormous importance for monitoring economic output and explaining price and wage inflation. It provides essential information for shaping economic and monetary policy of central authorities. Several methods are currently available to estimate potential output and output gap. In the current study, methods of Hodrick-Prescott filter and Cobb-Douglas production function were implemented to estimate potential output, which cannot be empirically observed. For the purpose of comparing the above methods, quarterly and annual time series of real GDP, labour and gross fixed capital starting in 1996 were used for estimation of the output gap. Relative contributions of labour, fixed capital formation and technology improvement factor towards growth of potential output were quantified for the studied series. The Cobb-Douglas production function appears to be superior to Hodrick-Prescott filter in providing quality estimates of potential output. Hodrick-Prescott filter allows estimation of potential output; nevertheless, it fails to identify components of cyclic behaviour of economic activity. Cobb-Douglas production function describes level of potential product assuming average utilization of production factors. A detailed analysis of components of economic growth in the observed period is provided.
\end{abstract}

economic cycle, potential output, output gap, Hodrick-Prescott filter, Cobb-Douglas production function

It is generally accepted that analysis of economic cycle can provide a multitude of valuable information about size of economic output and may help shed light on its relationship with the rates of employment and inflation. Central bank is primarily interested to learn, whether the current output is above or below its potential level. It attempts to steer short-term interest rates and volume of credit funds available to companies and citizens to support aggregate demand and influences the prospective difference between the actual and potential economic output, the output gap. Provided, a positive output gap occurred, the central bank usually responds to excess demand by increasing the interest rates to cut down inflation pressures and prevent overheating the economy. On the other hand, if the attained product is below its potential value, the bank responds to excess capacity by dropping the key interest rates to spur the economic growth. For this reason, estimating sign and magnitude of the output gap provides an essential piece of knowledge about phase of the economic cycle and thereby, it helps the authorities form correct macroeconomic policy.

Potential output and output gap for the Czech economy were previously estimated by Hájek and Bezděk (2000) and Blašková (2006). Zimková and Bachorovský (2007) compared competing approaches to estimation of output gap in Slovakia. In the current study, Hodrick-Prescott (H-P) filter and non-linear Cobb-Douglas (C-D) production function were applied to approximate the potential output and estimate the output gap in the Czech Republic. Quarterly and annual series of Czech GDP, labour and gross fixed capital, starting in 1996, were used in this effort. Relative contributions of labour, fixed capital formation and technology improvement towards growth of the potential output, were quantified for the whole economy, as well as for key sectors. 


\section{MATERIAL AND METHODS}

The real economic output can be empirically observed, however, its potential level must be approximated by statistical and econometric methods. Historically, two fundamental approaches were defined to derive the potential output: the first economic approach is based on the output associated with stable inflation. Its estimation utilizes production function or semi-structural models of the Phillips curve. The second statistical principle is based on estimating trend and cyclical components of actual output by filters, such as Hodrick-Prescott (EU Economic Policy Committee, 2001). Estimates of output gap are known to be sensitive to the broad model used, the concrete specification of the model and the sample period (De Brouwer, 2008).

The Cobb-Douglas production function is considered a structural method. It estimates the potential output independently of the economic cycle, conditioning on the average utilization of production factors

$Y_{t}=A_{t} \times L^{\alpha} \times K^{1-\alpha}$.

In the model equation, $Y$ is the actual or fitted output, $A$ is the factor of technology improvement, $L$ is potential labour and $K$ is capital. Coefficients $\alpha$ and $1-\alpha$ stand for relative elasticity of labour and capital on the output, respectively, estimated by average proportion of employee compensations to the output, both at current prices, according to OECD and IMF guidelines. From data of $L$ (mean number of labourers in the civilian sector) and $K$ (gross fixed capital), the $A$ variable is received as residuals from equation (1). Subsequent applying $\mathrm{H}-\mathrm{P}$ filter to the residuals produces smoothed trend of technology improvement factor $A^{\text {s. Potential }}$ output (GDP) is later estimated by fitting trend of technology improvement $A^{s}$, potential size of employment and capital (K) back to the equation (1).

The unobservable potential employment is calculated from

$$
L_{p o t}=P \times E P \times(1-N A W R U),
$$

where $P$ is productive population size between 15 and 64 years of age, EP is rate economic participation and NAWRU is H-P smoothed Non-accelerating Wage Rate of Unemployment, a minimum level of unemployment, which keeps labour costs stable. then reflects the maximum level of employment, which fails to contribute to mounting inflation pressure.

Several ways of estimating NAWRU unemployment rate exist. In this study, it was computed from the equation

$$
N A W R U_{t}=U_{t}-\left(\Delta U_{t} / \Delta^{2} w_{t}\right) \times \Delta w_{t},
$$

where $U_{t}$ is unemployment rate, $\Delta U_{t}$ is change of unemployment and $\Delta w_{t}$ is change of wages at time $t$.
Before use, the estimates of NAWRU rate are often smoothed by H-Pfilter. In theory, the unemployment rate is indirectly proportional to wage increase. In practice, wage growth may still occur with jobless rate above the NAWRU boundary (Zimková and Bachorovský, 2007).

H-P filter (Hodrick and Prescott, 1997) is identified by the loss function

$\min \left\{\sum_{t=1}^{T}\left(y_{t}-\hat{y}_{t}\right)^{2}+\lambda \sum_{t=2}^{T-1}\left[\left(\hat{y}_{t+1}-\hat{y}_{t}\right)-\left(\hat{y}_{t}-\hat{y}_{t-1}\right)\right]^{2}\right\}$,

where $y_{t}$ denotes the actual output data, $\hat{y}_{t}$ denotes the potential output and $\lambda$ is the smoothing constant selected for specific type of series or chosen by comparing H-P output of the same series smoothed with different values of $\lambda$. In general, H-P splits the series into trend and cyclic components by minimizing the sum of squared deviations of the data from the trend and simultaneously controlling oscillations of the trend. The difference $c_{t}=y_{t}-\hat{y}_{t}$ then denotes the cyclical component, the dimensional output gap (Zimková and Bachorovský, 2007).

Application of $\mathrm{H}-\mathrm{P}$ filter is easy and independent of specific type of data. The quality of estimated potential output, nonetheless, depends on the correct choice of $\lambda$. Zero value provides no apparent smoothing, while extreme value of $\lambda$, on the other hand, produces deterministic regression line (Razzack and Dennis, 1999). Further, in particular situations, the potential output estimated by H-P filter may be distorted at ends (Hájek and Bezděk, 2000) due to increased weight placed on marginal observations or the H-P filter may induce nonexistent cycle (Harding, 2002). Method of extending the series with extrapolated linear or polynomial trend exists to overcome this problem (Blašková, 2006). The relative output gap [\%] is then received by applying $g_{t}=100 \times\left(y_{t}-\hat{y}_{t}\right) / \hat{y}_{t}$. Statistical estimation and construction of plots were conducted with R software (www.r-project.org), v. 2.14.0 and Gnu Regression Econometrics and Timeseries Library (http://gretl.sourceforge.net), v. 1.9.5.

\section{RESULTS AND DISCUSSION}

Quarterly data: time series of quarterly GDP at prices fixed on the average of the previous year (source: czso.cz), was seasonally adjusted by TRAMO/SEATS (Caporello and Maravall, The Bank of Spain) and extended with 2-year predictions from cubic trend. Subsequent H-P filter with $\lambda=1600$ estimated the potential product and cyclic component to be used for calculation of relative output gap (Fig. 1). Currently, two full economic cycles can be seen on the plot. The H-P method, however, lacks the capability to identify distinct components behind the detected cycles.

Percentage output gap was additionally estimated from the quarterly data with the Cobb-Douglas function (1) using mean elasticity parameter of labour $\alpha=0.433$. H-P derived trend of technology 


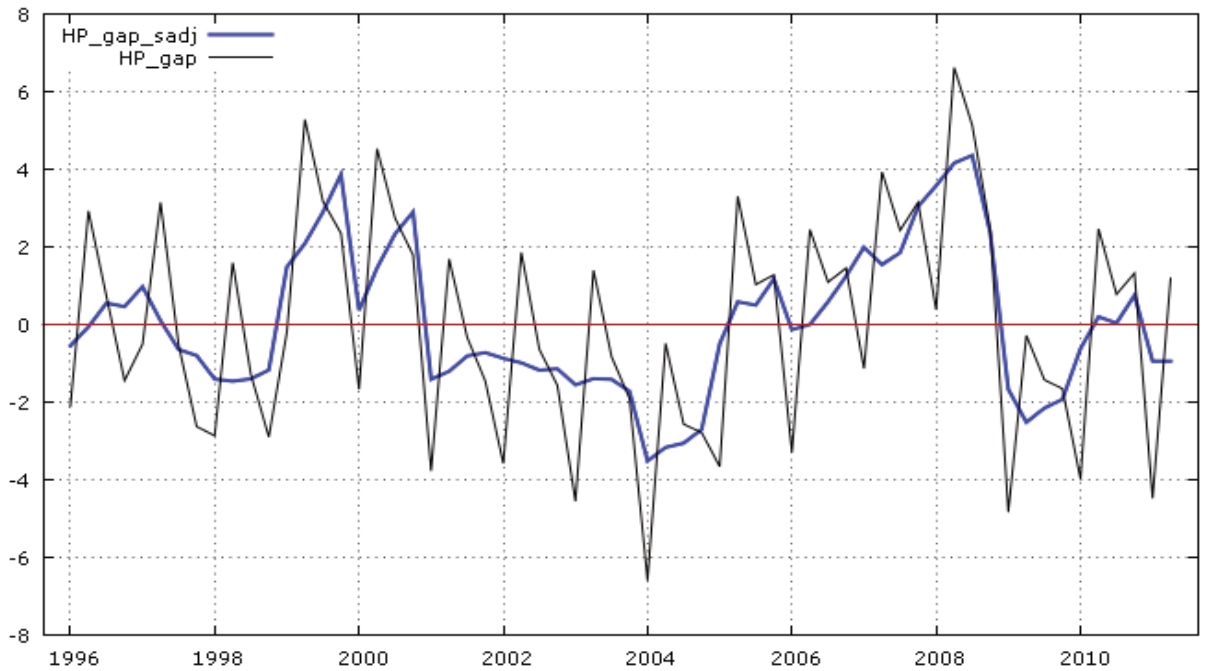

1: Output gap estimated by H-P filter from raw and seasonally adjusted quarterly data

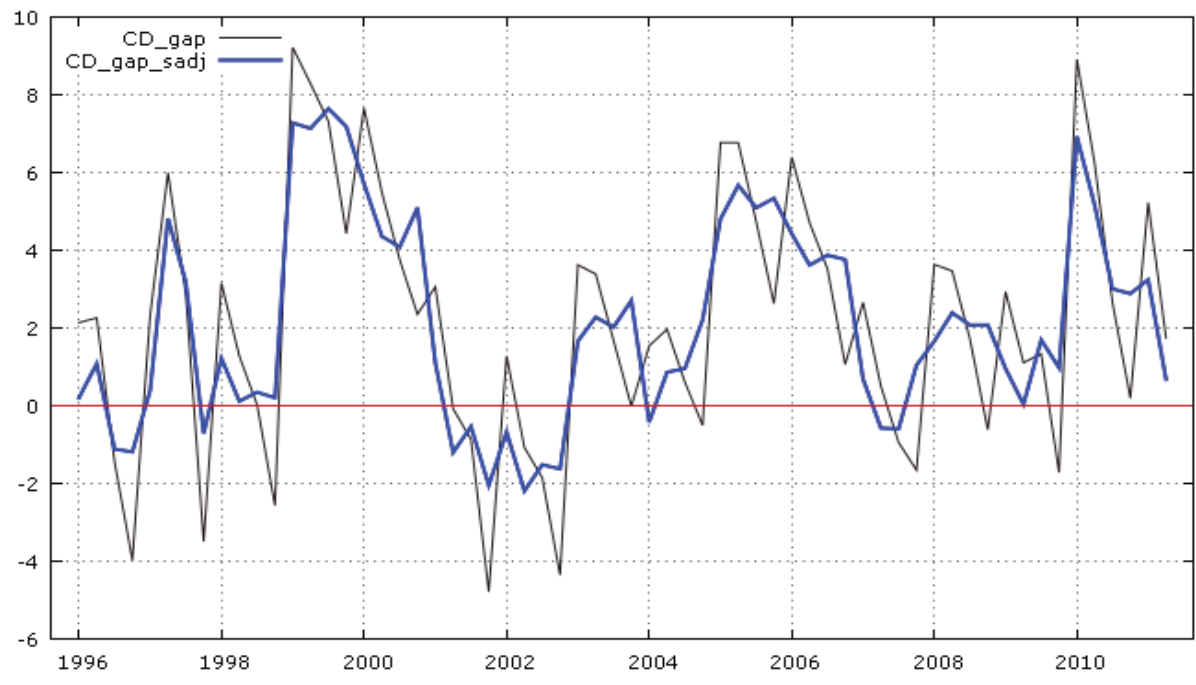

2: Unadjusted and seasonally adjusted output gap by Cobb-Douglas production function [\%]

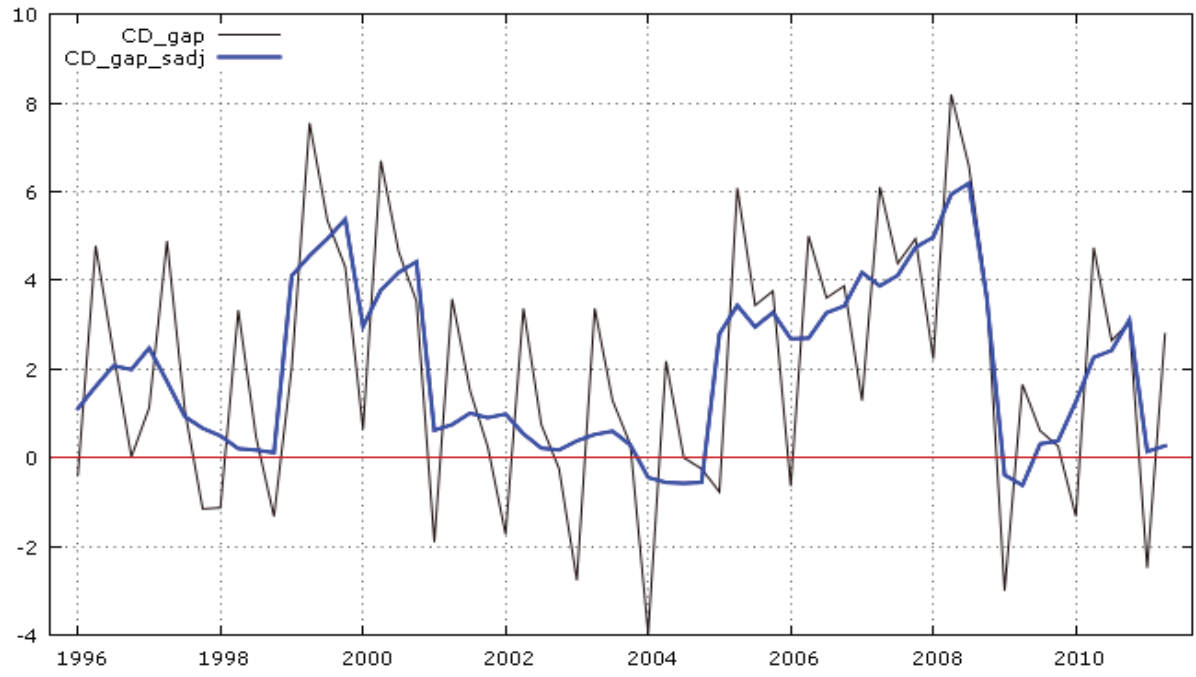

3: Unadjusted and seasonally adjusted output gap from combined components of the Cobb-Douglas function [\%] 
improvement factor $A^{\text {s }}$, potential employment from (2) using NAWRU rate from (3) and non-smoothed gross fixed capital gave the potential output and output gap (Fig. 2). An alternative approach to output gap estimation (Fig. 3) was explored using components of relative growth in $A, K$, and $L$ deviated from respective smoothed trends or $L_{\text {pot }}$ and combined with (1) pursuing approach by Zimková and Bachorovský (2007). Differences between these approaches can be attributed to empirical gross fixed capital used to assemble the equilibrium output in Fig. 2. Also, it leads to the conclusion that the period of intensive growth accompanied by positive gap in years 2005 to 2008 was strongly driven by accelerating level of investments. A strong similarity of the combined C-D component estimates with output gap by H-P filter is established (Fig. 1).

Presently, the Czech economy is found at the stage of gradual recovery from the economic slowdown triggered by economic and financial crisis in the USA and Western Europe. Dependency of the Czech output growth on the magnitude of economic expansion in the Eurozone suggests, that the recovery phase is likely to be moderate and protracted.

Annual data: potential output and output gap were additionally obtained from annual GDP, and gross fixed capital data from the Quarterly National Accounts expressed at previous year's average prices. Employment data were accessed from Total Employment for the economy and sectors of the economy (source: czso.cz). Labour force and Non-accelerating Wage Rate of Unemployment (NAWRU) data were received from the Ameco annual macroeconomic database of the European Commission Directorate for Economic and Financial Affairs (http://ec.europa.eu/economy_ finance/ameco). Several estimation approaches to potential output were put into practice: H-P filter was applied to unadjusted extended GDP data with smoothing constant $\lambda=100$. Cobb-Douglas production function estimated the potential output with mean elasticity parameter $\alpha=0.433$. Estimated output gap for years 1996-2010 by C-D production function, C-D combined components method and $\mathrm{H}-\mathrm{P}$ filter is presented in Fig. 4. Obtained estimates can be compared to yearly output gap retrieved from the Ameco database of the European Commission.

The applied estimation methods produced not entirely identical, but rather similar estimates of output gap. Periods of excess demand appear to have taken place in years 1999 and 2001 and again primarily between 2005 and 2008. The later period was accompanied by progressively rising inflation due to surplus demand, growing prices of raw materials, fuel and energy and implemented reforms of income tax and VAT. The central bank successively responded by increasing the key interest rate. Periods of excess capacity were noticeable during years 2002 to 2004 and again in 2009 and further. Depicted patterns of economy expansion and contraction corresponding to its equilibrium potential obtained from the yearly data are in agreement with output gap estimated from the quarterly data. Relative representation of the Cobb-Douglass production curve components: total factor productivity (TFP), labour and capital; offer further insight into attributes of the total output growth (Tab. I). It appears, that primarily gross capital formation (investments) and technology improvement factors provided the leading momentum to the Czech economic growth, during the analyzed period. In this context, investment incentives introduced by the Czech government for the foreign investors in 2001 proved to be an important aspect of the economic prosperity that followed.

Tab. II shows relative year-to-year growth of the potential output and its C-D model components. The significant components for Czech potential

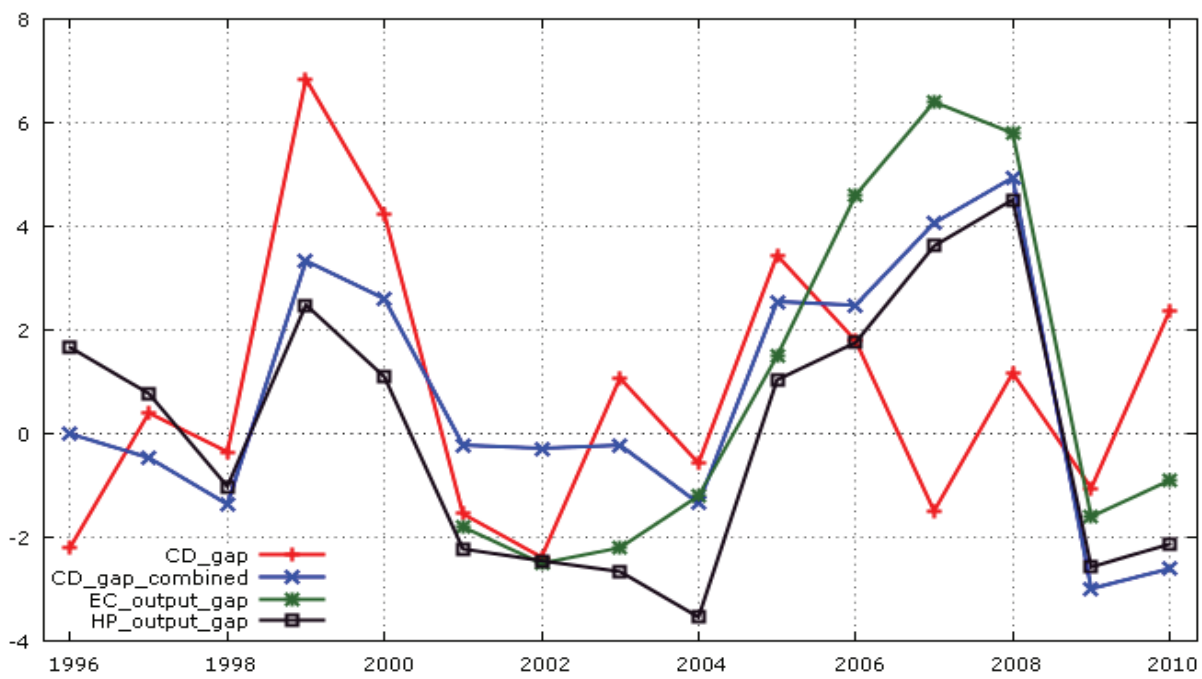

4: Estimated output gap from annual data by Cobb-Douglas, Cobb-Douglas component method, H-P filter() and the Ameco EC database 
I: Factor contributions towards relative output gap [\%]

\begin{tabular}{ccccc}
\hline & $\begin{array}{c}\text { Output } \\
\text { gap }\end{array}$ & TFP & Labour & Capital \\
\hline 1996 & 0.0 & -3.5 & 3.3 & 4.0 \\
1997 & -0.5 & -0.5 & 2.2 & -1.5 \\
1998 & -1.4 & -0.9 & 1.4 & -1.8 \\
1999 & 3.3 & 6.9 & -0.1 & -5.7 \\
2000 & 2.6 & 3.8 & 0.9 & -2.7 \\
2001 & -0.2 & -2.5 & 2.4 & 2.4 \\
2002 & -0.3 & -3.7 & 3.2 & 3.8 \\
2003 & -0.2 & 0.1 & 2.3 & -2.2 \\
2004 & -1.3 & -1.4 & 1.9 & -1.4 \\
2005 & 2.6 & 3.0 & 1.0 & -1.5 \\
2006 & 2.5 & 1.4 & 1.0 & 1.2 \\
2007 & 4.1 & -2.7 & 2.9 & 10.2 \\
2008 & 4.9 & -0.6 & 4.2 & 6.7 \\
2009 & -3.0 & -1.5 & 1.2 & -3.4 \\
2010 & -2.6 & 2.1 & 0.5 & -8.4 \\
\hline
\end{tabular}

output growth are mainly capital accumulation and total factor productivity. From the output gap standpoint, the Czech economy is currently found in the period of surplus capacity with low risk of inflation and steady or slowly rising unemployment. With poor outlook for growing employment and increase in capital investments, the technology improvement factor is likely to be the remaining source of economic output growth, in this period.

Sector analysis: In the following section, we shall investigate participation of selected key sectors of the Czech economy defined by OKEČ classification system of economic activities on growth of the domestic product and output gap. Annual data for the sector analysis of agriculture and fisheries, manufacturing industry and construction sector were taken from sheets Resources of GDP, GDP
II: Factor contributions towards relative growth of potential output [\%]

\begin{tabular}{ccccc}
\hline & $\begin{array}{c}\text { Potential } \\
\text { GDP }\end{array}$ & TFP & Labour & Capital \\
\hline 1997 & 6.7 & 5.9 & 1.2 & 0.4 \\
1998 & 8.4 & 5.5 & -0.8 & 5.4 \\
1999 & 5.0 & 5.2 & -2.0 & 1.2 \\
2000 & 9.3 & 4.8 & -1.1 & 8.6 \\
2001 & 10.1 & 4.5 & -1.0 & 10.5 \\
2002 & 7.8 & 4.3 & -0.2 & 6.1 \\
2003 & 2.9 & 4.1 & -0.5 & -1.8 \\
2004 & 7.2 & 4.0 & 0.7 & 5.0 \\
2005 & 6.8 & 3.8 & 2.0 & 3.6 \\
2006 & 8.2 & 3.7 & 2.0 & 6.3 \\
2007 & 10.9 & 3.6 & 0.7 & 12.2 \\
2008 & 3.1 & 3.5 & 0.0 & -0.6 \\
2009 & -0.2 & 3.4 & 1.8 & -7.3 \\
2010 & 1.4 & 3.3 & -0.2 & -3.0 \\
\hline
\end{tabular}

from the Income Side (employee compensations by sector), Gross Fixed Capital Formation by Sectors (annual accounts) and Total Employment (source: czso.cz). When estimating the potential output by sectors, only the structural method of CobbDouglas was considered. Due to shortage of suitable data for sectors, potential labour $L_{\text {pot }}$ series was approximated by sector employment data smoothed by H-P filter with constant $\lambda=100$. Relative output gap from C-D function and by combining the C-D curve components, were estimated.

For the sector of agriculture and fisheries, we calculated the mean elasticity parameter of labour $\alpha=0.466$. Estimated output gap for agriculture is presented in Fig. 5. It can be reasoned that output of agricultural sector is strongly influenced by climate, crop rotation plan, commodity prices and

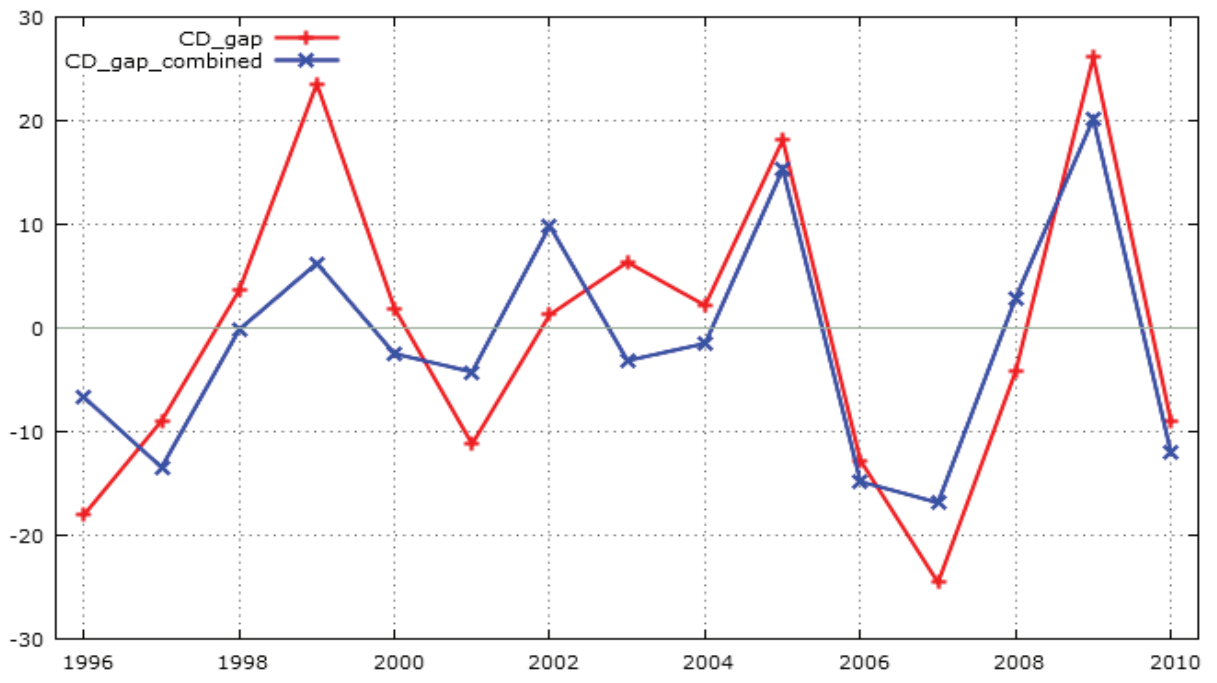

5: Estimated output gap from annual data by Cobb-Douglas and Cobb-Douglas component methods for the agriculture and fisheries 


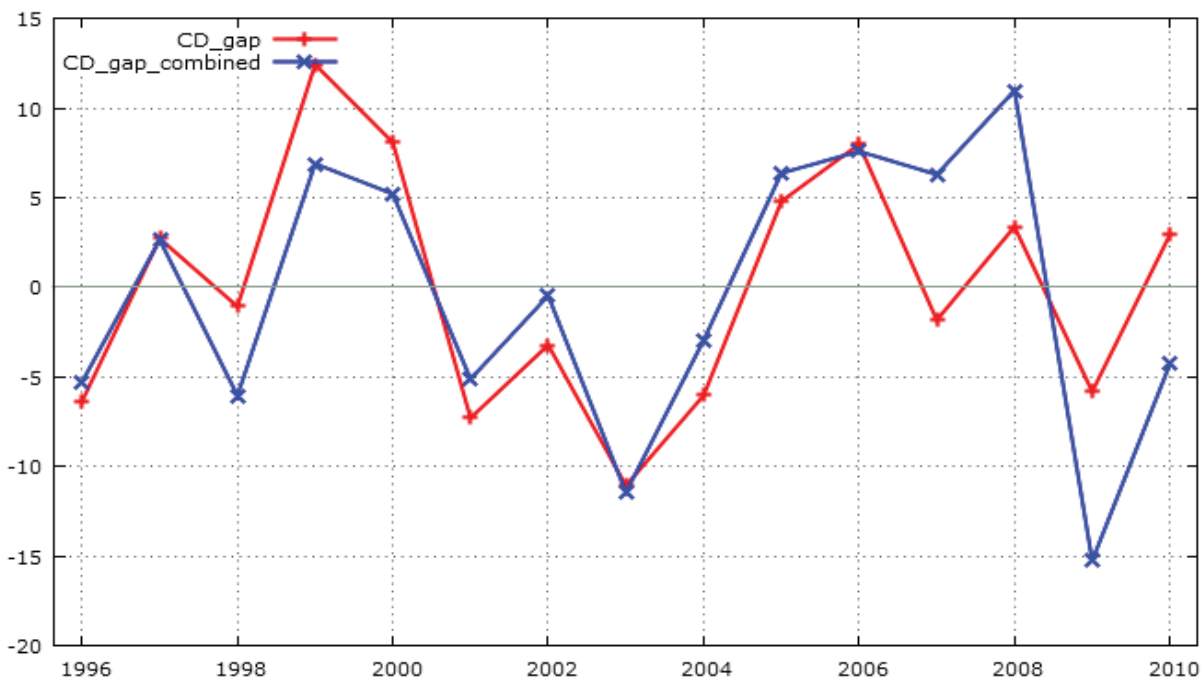

6: Estimated output gap from annual data by Cobb-Douglas and Cobb-Douglas component methods for the industry

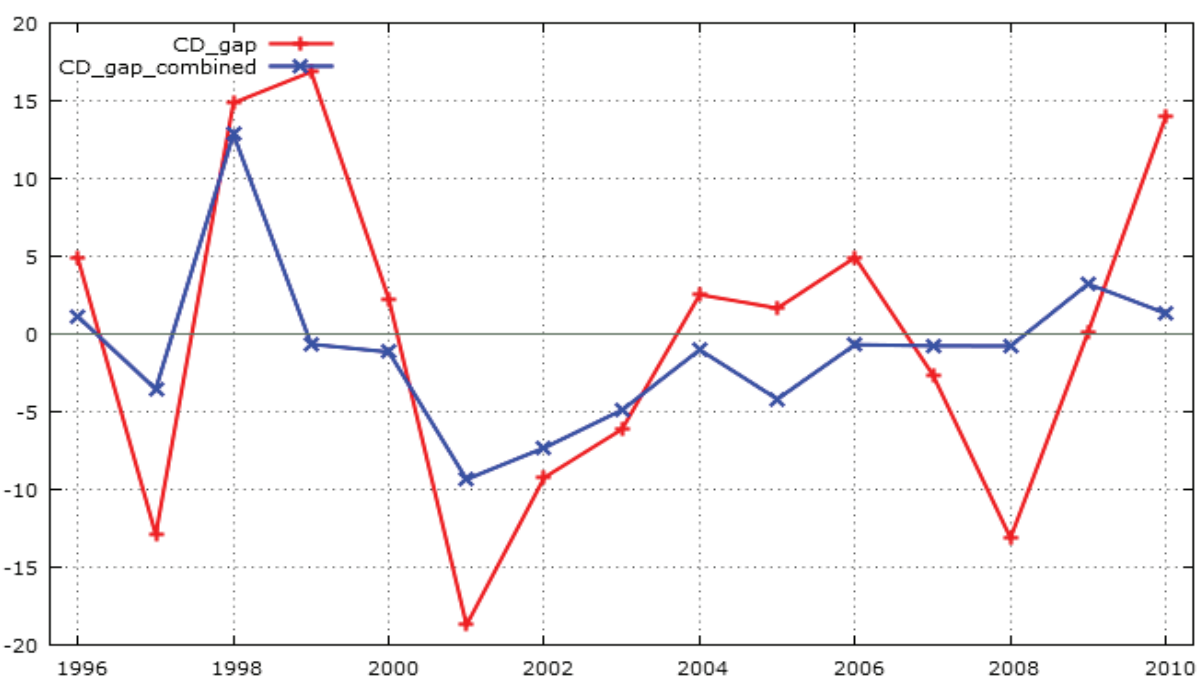

7: Estimated output gap from annual data by Cobb-Douglas and Cobb-Douglas component methods for the construction sector

prices of raw material, fuel and energy. For this reason, it is likely to show pattern of excess demand or capacity inconsistent with the general Czech economic cycle. In the analyzed period, growth of the potential product in agriculture and fisheries was driven primarily by the total factor productivity component.

Average elasticity parameter of labour $\alpha=0.517$ was estimated for the manufacturing industry, which is to great extent influenced by demand and economic activity on key export markets for Czech products and services in the Eurozone. For this reason, pattern of output gap in manufacturing industry corresponds to estimated output gap in the whole Czech economy (Fig. 6).

For the construction sector, the average elasticity parameter of labour was $\alpha=0.472$. It is evident, that pattern of output gap in the construction sector displays lack of conformity with the whole Czech economy (Fig. 7). This observation could be attributed to specific conditions influencing economic output in the Czech construction sector, such as climate and availability of credit financing.

\section{CONCLUSIONS}

Potential output and output gap estimated by Hodrick-Prescott filter and Cobb-Douglas function produced varying results, when applied to quarterly and annual data of Czech GDP, labour and gross fixed capital. In some cases, the estimates from different methods lead to conflicting conclusions regarding the actual phase of economic cycle. Since the output gap depends on the estimation method, assumptions made and the sample data, it is difficult to estimate the absolute size of the gap (de Brouwer, 2008). The observed differences can 
be explained by known limitations of the H-P filter, primarily the problem with smoothing data at ends, implicit symmetry of $\mathrm{H}-\mathrm{P}$ derived output gaps or weakened impact unexpected supply or demand shocks may exerted on the estimated trend. Output gap from quarterly and annual data nonetheless yielded similar results with the same estimation method used. Combined component method and
H-P filter produced similar estimates of output gap, which differed more apparently on the edges. In the Cobb-Douglas function, obtaining a precise enough estimate of the NAWRU rate can be challenging (Giorno et al., 1995). The C-D production function method, however, generates additional information about causes behind the cyclic behaviour of the observed output.

\section{SUMMARY}

In this study, competing methods of Hodrick-Prescott filter and Cobb-Douglas production function were compared with regard to estimation of the Czech Republic potential output and output gap. Quarterly and annual series of GDP, labour and gross fixed capital during 1996-2010 were used in this effort. NAWRU rates of unemployment were calculated (quarterly data) or were taken from the EC Ameco database (annual data). Relative contributions of labour, fixed capital formation and technology improvement towards growth of the potential output and output gap were quantified for the whole economy. Estimates of potential output and output gap were consistent for quarterly and annual data, but differed across methods of estimation. The observed differences can be explained by weaknesses of the named methods and data used. It was evident from the analysis of quarterly data, that period of intensive growth accompanied by excess demand during 2005-2008 was facilitated primarily by high level of investments and capital accumulation and to lesser extent by total factor productivity. Czech government incentives for foreign investors, launched in 2001, were shown to be favorable for future economic growth. Also, similar output gap from the combined C-D component and $\mathrm{H}-\mathrm{P}$ filter methods was produced in quarterly and annual data.

Production function data for key sectors of the Czech economy by OKEČ system of classification of economic activities: agriculture and fisheries, manufacturing industry and construction sector were used to estimate potential output and output gap by C-D function and the combined components approach. Resemblance of patterns of production output and output gap in manufacturing industry and the Czech economy was established, but in the other sectors, the patterns were inconsistent. Univariate approach of the production function appears superior to $\mathrm{H}-\mathrm{P}$ filter, since it provides additional information about reasons for cyclic character of the economic activity.

\section{REFERENCES}

BLAŠKOVÁ, V., 2006: Metody odhadu produkční mezery, Proceedings to the conference International Scientific Days, 2006, Faculty of Economic and Management SAU in Nitra, May 2006, p. 13321340.

DE BROUWER, G., 2008: Estimating output gaps. Reserve Bank of Australia, Research Discussion Paper No. 9809.

EU Economic Policy Committee: Report on the potential output and the output gap, 2001, EU economic publications, http://europa.eu/epc/ pdf/finaloutput_en.pdf.

GIORNO, C., RICHARDSON, P., ROSEVEARE, D. and VAN DEN NOORD, P., 1995: Potential output, output gaps and structural budget balances, OECD Economic Studies No. 24, I995/1, p. 167-209.
HÁJEK, M., and BEZDĚK, V., 2000: Odhad potenciálního produktu a produkční mezery v ČR, working paper No. 26, Česká národní banka Praha, www.cnb.cz.

HARDING, D., 2002: The Australian Business Cycle: A New View, MPRA archive, http://mpra.ub.unimuenchen.de.

HODRICK, R. J. and PRESCOTT, E. C., 1997: PostWar U.S. business cycles: A descriptive empirical investigation, Journal of Money Credit and Banking, 29, p. 1-16.

RAZZAK, W. A. and DENNIS, R., 1999: The output gap using the Hodrick-Prescott filter with a nonconstant smoothing parameter: an application to New Zealand.

ZIMKOVÁ, E. and BACHOROVSKÝ, J., 2007: Odhad potenciálneho produktu a produkčnej medzery V slovenských podmienkach, Politická ekonomie, 4, 2007, p. 473-489.

doc. Ing. Václav Adamec, Ph.D., Ing. Luboš Střelec, Ph.D., Ústav statistiky a operačního výzkumu, Mendelova univerzita v Brně, Zemědělská 1, 61300 Brno, Česká republika, e-mail: vadamec@mendelu.cz, lubos. strelec@mendelu.cz 
